\title{
RANGE EXTENSION OF PURPLE CONE-FLOWER IN SOUTHEASTERN SASKATCHEWAN
}

\author{
by B. DE VRIES*
}

The main references to the distribution of the Purple Cone-flower (Echinacea angustifolia D.C.) in Saskatchewan are given in Breitung's $A n$ notated Catalogue of the Vascular Flora of Saskatchewan, Budd and Best's Wild Plants of the Canadian Prairies, and Boivin's Flora of the Prairie Provinces, Part III. ${ }^{2} \quad 3 \quad 1$ These sources list the Purple Cone-flower as an occasional to common indigenous entity of the prairie flora on dry river-banks and benchlands in southeastern Saskatchewan.

In an endeavor to locate all known collecting stations of this plant species prior to and after 1957 north of the 49 th parallel, the following institutions have been of assistance: Biosystematic Research Institute, Agriculture Canada, Ottawa (DAO); National Herbarium of Canada, National Museum of Canada, Ottawa (CAN); Fort Qu'Appelle Herbarium, Fort Qu'Appelle, Saskatchewan (FQH); Gray Herbarium, Harvard University, Cambridge, Massachusetts (GH); Museum of Natural History, Regina, Saskatchewan (MNR); Herbarium of the New York Botanical Garden, (NY); Research Station, Agriculture Canada, University Campus, Saskatoon, Saskatchewan (RAS);

\footnotetext{
*Fort Qu'Appelle Herbarium, P.O. Box 1043.

Central Ave.

Fort Qu'Appelle, Saskatchewan.

SOG ISO
}

Research Station, Agriculture Canada, Swift Current (SCS); Fraser Herbarium, University of Saskatchewan, Saskatoon, Saskatchewan (SASK); Herbarium, University of Alberta, Edmonton, Alberta (ALTA); Herbarium, University of Calgary, Calgary, Alberta (UAC); Herbarium, University of Regina, Regina, Saskatchewan (USAS); United States National Museum, Washington, D.C. (US); Herbarium, University of Manitoba, Winnipeg, Manitoba (WIN).

The author is grateful to Mrs. G. M. Keleher, Department of Botany, University of Manitoba, Winnipeg, for the loan of voucher material, and to all other institutions for their helpful information on Echinacea angustifolia collections. The fieldwork was supported by private funds.

The following is an enumeration of collecting data:

ONTARIO: $J$. White 59062 (CAN 106685), Brampton, C.P. Railway, July 10, 1902.

MANITOBA: N. Criddle (CAN 196884), Aweme, July 30, 1926; H. J. Scoggan 10950 (CAN 224145), Aweme, 15 miles southeast of Brandon, dry prairie, June 27. 1953; C. W. Lowe (WIN 7970), Baldur, dry prairie August 13, 1941; Macoun 13927 (CAN 106686, NY 13927), Brandon, dry open prairie, July 24, 1896; idem 11470 (CAN 106687), Brandon, open prairie, September 11, 1884: J. Fletcher 956 (DAO), Brandon, open prairie, 1895; Budd and Hubbard 2 (SCS), Brandon, July 22, 1946; H. H. Marshall $I$ (DAO), Brandon, dry hills, July 28, 1947; G. A. Stevenson 5/3 (DAO), Brandon, common on open prairie, July 13, 1952; $H$. J. Scoggan 9724 (WIN 7965, CAN 2100544), east of 
Brandon Spruce Woods Forest Preserve sandy soil, July 18, 1951; J. Fletcher (DAO), Carberg Plain, prairies, 1896: Askell and Doris Löve 6I00 (WIN 7971, DAO, GH), 6 miles north of Clearwater S21 T3 R 12, dry roadside, July 16, 1953 , W. Marquardt (WIN 7968), Fort Garry University Campus, Manitoba Agricultural College, July, 1930; J. $A$. Donaghy (WIN 7967 and 7969), Grund, S10 and 11 T5 R 14, near Grund Church on Balder road, July 28, 1924; $H$. Groh (DAO), La Riviere, prairies, June 19 , 1932: H. A. Wallace 449A-280 (DAO), Melita, meadow, July 26, 1946: B. Boivin and $A$. J. Breitung 6559 (DAO), Melita, slightly pastured gravelly natural prairie near creek, July 19, 1949; H. J. Scoggan 9759 (CAN 210546), Melita, in southwest corner of province, grassy prairie, July 20, 1951; idem 1/073 (WIN 7964), Melita, rolling prairie, July 2, 1953 (CAN 224146); D. Löve and B. Boivin 6340 (WIN 7966), Melita, dry prairie, July 12, 1954; Askell and Doris Löve 6018 (WIN 7972, US 2131877, DAO, GH, SASK), 1 mile west of Ninette, S13 T5 R 17, prairie, July 14, 1953; Gérard de Ruyck (DAO), Rock Lake, Coulée Pembina, Lacs du Plate-Côté, 16 Juillet 1947; C. Cranston 76 (DAO) 1-1/2 mile south of Shilo on Treesbank Trail MacDonald District, fire-guard, sandy soil, shade absent, stems quite prickly, August 23, 1950; B. Boivin and $W$. $G$. Dore 8255 (WIN 7963, DAO, NY, SCS, SASK, ALTA, USAS), 2 miles west of Shilo, Macdonald District, sandy soil, July 24, 1951;J. M. Walker 5337 (WIN 20119), Shilo, prairie, August 1968; Thos. L. Walker (DAO), Souris County, July 1, 1889: H. J. Scoggan 9745 (CAN 210545), Souris River, north of Minto, prairie, July 18, 1951 (ALTA); M. Hoefs (WIN 7962), Spruce Hills Forest Preserve, open meadow, very dry habitat, August 1966: H. J. Scoggan 11410 (CAN 224147), Wawanesa, 20 miles southeast of Brandon, denuded prairie at crest of slope above Souris River, July 24, 1953.

SASKATCHEWAN: B. Boivin 8438 (DAO), 2 milles à l'est d'Alameda, Rivière de la Montange à l'Original, Ecorre de la vallée, 2 aoû́t, 1951 (SASK): R. Hooper 7135 (FQH 4335), Big Beaver, dry slopes, July 20, 1972; J. L. Bolten 154 (SASK, MNR, RAS, SCS), Carnduff, dry slopes, July 15, 1938; C. W. Lowe (WIN 7975, 7976), Estevan, dry sandy soil, July 3,$1939 ; W . G$. Dore and $A$. $J$. Breitung 12568 (DAO), Estevan, dry slopes badlands along Souris River, August 14, 1950; B. Boivin and $W . G$. Dore 7982 (DAO, ALTA, USAS),
Estevan, lower part of cliff bordering the valley of the Souris River, July 17. 1951: T. M. Willing 456 (DAO, SASK), south of Estevan, July 11, 1900; J. Looman 65I (SCS, FQH 3372), Frobisher, August 15. 1962: D. Löve and B. Boivin 6353 (WIN 7974 ) Glen Ewen, dry prairie, July 13, 1954: B. Boivin, D. Löve, and D. Dunbar 10294 (DAO), Glen Ewen, Ecorre de la coulée Souris, 13 juillet 1954; B. Boivin and A. J. Breitung 6602 (DAO), Glen Ewen, upper part of dry bluff along Souris River, July 20, 1949; $G$. F. Ledingharn and S. Yip 2267 (USAS), 2 miles south of Glen Ewen, open prairie slopes above Souris River. July 11, 1956: idem 2307 (USAS), 10 miles southeast of Hirsch, open grassy slopes above Souris River, August 11, 1956: H. Morrison 68$36 I$ (SASK), Lower Big Muddy Valley, S1 T2 R22 W2, dry hillside, fairly common, July 30, 1968: B. Boivin and $W . G$. Dore 7943 (WIN 7973, DAO, NY, SCS, UAC), south of Macoun, dry south-facing embankment of the valley of the Souris River, July 16, 1951; H. Groh (DAO), Oxbow, prairies, June 27,$1932 ; W . G$. Dore and A. J. Breitung 12594 (DAO), Oxbow, natural prairie on slope of Souris River Valley, rays absent, disk florets abnormal, August 14, 1950: ide'm 12595 (DAO), Oxbow, abundant on grassy slopes of Souris River Valley, rays lilac. August 14, 1950; B. Boivin and $W . G$. Dore 8048 (DAO). Oxbow, dry southfacing slope of escarpment bordering the valley of the Souris River, July 19, 1951; J. B. Campbell (SCS), Roche Percee, July 31, 1945; B. Boivin and W. G. Dore 8013 (DAO, SASK), Roche Percee, lower part of rockslide below sandstone cliff bordering the valley of the Souris River, July 17, 1951: B. de Vries 5133 (FQH 3373), Round Lake, Qu'Appelle Valley, southfacing slope, open exposure, August 5 , 1971; idem 5994 (FQH 0171), Round Lake, Qu'Appelle Valley, open slopes between Grimeau Park and Maple Grove, July 7, 1974: G. F. Ledingham and M. D. Fahselt 3601 (USAS), Round Lake, 45 miles northeast of Regina, dry slopes of the Qu'Appelle Valley, August 4. 1963: R. C. Russell (RAS), Round Lake, Stockholm, dry hillside, June 19, 1937: idern 557090 (DAO), Stockholm, near base of hillside along the Qu'Appelle Valley, June 19, 1937; E. H. Moss 2508 (ALTA), Weyburn, July 3, 1932; E. Bourgeau (GH), Saskatchewan, Palliser's British North American Exploratory Expedition, 1857-1858.

Under study it became apparent that the Purple Cone-flower is well 


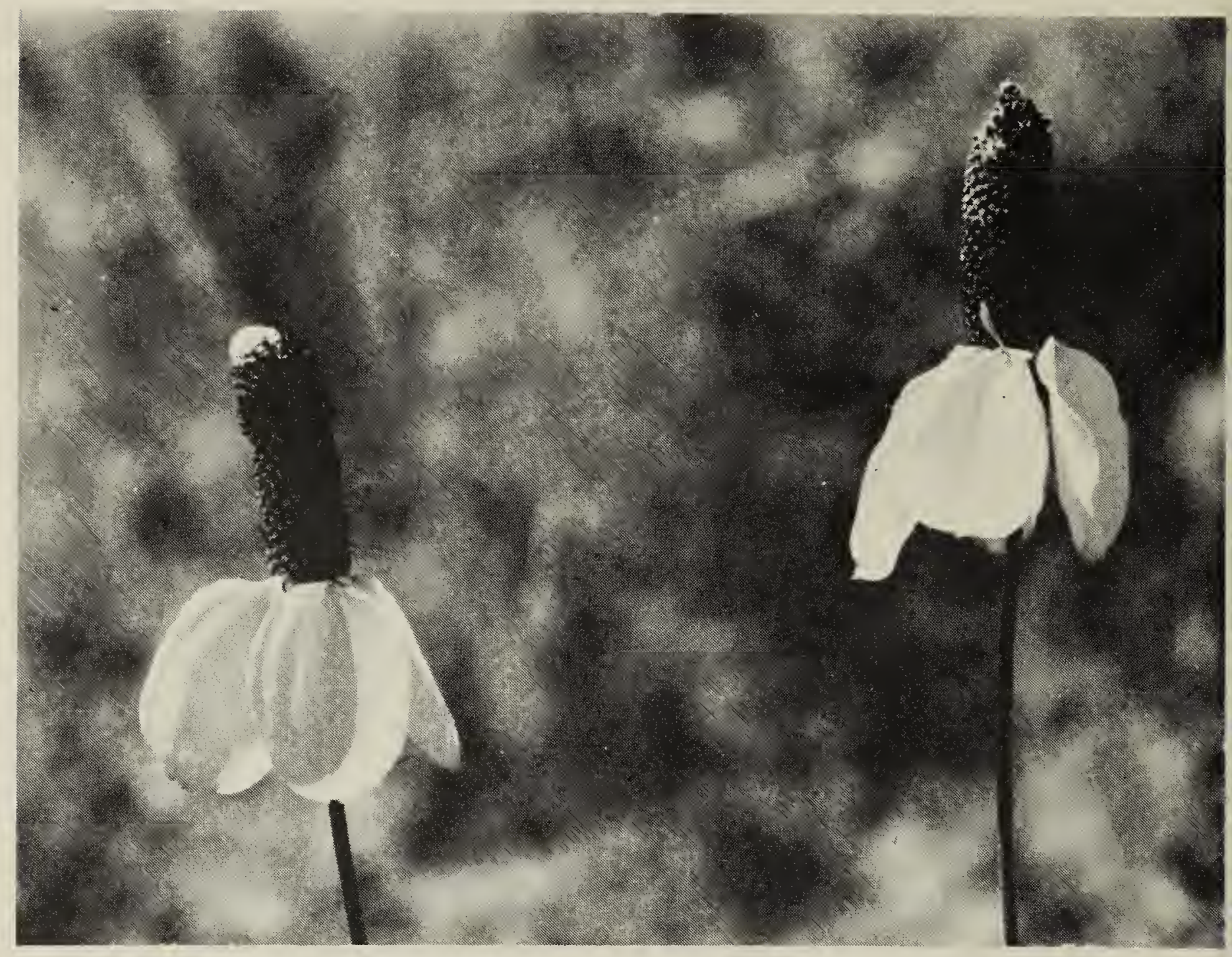

Prairie (Long-headed) Coneflowers.

R. E. Gehlert

distributed throughout temperate North America, ranging from Texas north to Colorado and Montana, east to Oklahoma and Minnesota, and occurs in southern Ontario and Manitoba, and as disjunct populations in southeastern Saskatchewan.

On many field trips over the prairies, the author's attention was focussed on a possible north or westward range extension of this plant species. Subsequently a northwestward extension was discovered in the Qu'Appelle Valley in southeastern Saskatchewan on July 18, 1974. Well established populations occur in a tributary coulee northwest of Lebret, 5 miles east of Fort Qu'Appelle, on open slopes. Voucher specimens are represented in the Fort Qu'Appelle Herbarium under De Vries 6989 (FOH 0176).

The first record of Echinacea angustifolia for the prairie provinces is based on a collection by Bourgeau from "Saskatchewan" on Palliser's British North American Exploratory Expedition, 1857-1858. As only the locality, "Saskatchewan", was indicated and both Saskatchewan and Manitoba were then a part of the Northwest Territories, the geo- 
graphical location of this collection is very imprecise. The first record of the species from Manitoba is based on a collection by Macoun (No. 11470) from Brandon in 1884.

The 1937 collection of Echinacea angustifolia by Russell, represents a first northward extension in southeastern Saskatchewan. His geographic documentation is somewhat vague and in all likelihood he meant an area between the junction of Highways 9 and 247 and Birds Point along the north wall of the Qu'Appelle Valley near Round Lake, where subsequent collections of this plant species have been made.

The unusual disjunction between stations in southern Saskatchewan and the Qu'Appelle Valley, a direct line of approximate $150 \mathrm{~km}$ (90 miles), warrants consideration. The occurrences in southern Saskatchewan, from Carnduff to Estevan, are in contiguity along Highway 18 and indicate clearly that Echinacea angustifolia is indigenous to the mixed prairie (StipaBouteloua) association. Big Beaver in the Lower Big Muddy Valley is presently the known western limit. The two localities in the Qu'Appelle Valley, on the other hand, occur in the Aspen Grove formation of southeastern Saskatchewan, and are part of the Stipa-Bouteloua-Agropyron faciation with close affinity to xeric loam of open slopes. They appear to be the known northern outliers of the more widely spread populations in southern Saskatchewan.

The present study describes the distributional pattern of Echinacea angustifolia in southeastern Saskatchewan, which to the best knowledge of the author, has not previously received detailed investigation. The distribution maps of the original monograph of the genus Echinacea by McGregor (1968) stopped short of the United States-Canadian border (personal communication, Harms, 1974), and only one Saskatchewan (Estevan, Dore and Breitung 12568) and two Manitoba (Ninette, $A . \& D$. Löve 6018 ; Brandon, J. Macoun 13927) specimens were cited in the text.

'BOIV IN, B. 1972. Flora of the Prairie Provinces, a handbook to the flora of the provinces of Manitoba, Saskatchewan, Alberta, Part III. Provancheria 4, Memoires de l'Herbier Louis Marie, Faculté d'Agriculture, Université Laval, and Department of Agriculture, Ottawa 1-224.

${ }^{2}$ BREITUNG, A. J. 1957. Annotated catalogue of the vascular flora of Saskatchewan. American Midland Naturalist 58: 1-72.

'BUDD, A. C. and K. F. BEST. 1964. Wild Plants of the Canadian prairies. Canada Department of Agriculture, p. 1-519.

${ }^{+}$McGREGOR, R. L. 1968. The taxonomy of the genus Echinacea Compositae, University of Kansas Science Bulletin, Vol. 48: 113-370.

¿SCOGGAN, H. J. 1957. Flora of Manitoba. National Museum of Canada Bulletin No. 140 , p. $1-619$.

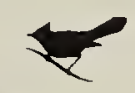

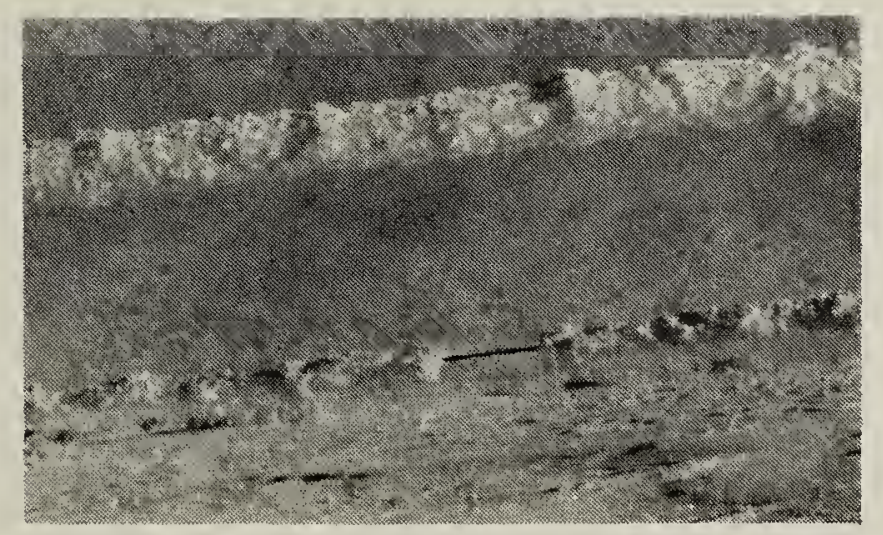

Hoar frost on barbed wire.

J. B. Gollop

Next two pages:

Purple Lesser Fritillaries on Goldenrod.

Fred Lahrman 